\title{
ASSESSMENT OF WATER SANITATION FACILITIES UTILIZATION AMONG THE RURAL HOUSEHOLDS OF SOUTHWESTERN NIGERIA
}

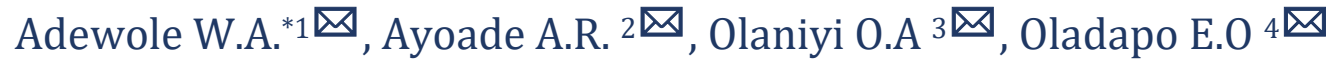 \\ ${ }^{*}$ Assistant Lecturer, Department of Agricultural Extension and Rural Development, Ladoke \\ Akintola University of Technology, Ogbomoso, Nigeria \\ 2 Professor of Rural Sociology, Department of Agricultural Extension and Rural Development, \\ Ladoke Akintola University of Technology, Ogbomoso, Nigeria \\ 3 Professor of Agricultural Extension communication, Department of Agricultural Extension and \\ Rural Development, Ladoke Akintola University of Technology, Ogbomoso, Nigeria \\ 4 Doctoral Students, Department of Agricultural Extension and Rural Development, Ladoke \\ Akintola University of Technology, Ogbomoso, Nigeria
}

DOI: https://doi.org/10.29121/granthaalayah.v9.i3.2021.3567

Article Type: Research Article

Article Citation: Adewole W.A., Ayoade A.R., Olaniyi O.A, and Oladapo E.O. (2021). ASSESSMENT

OF WATER SANITATION

FACILITIES UTILIZATION AMONG

THE RURAL HOUSEHOLDS OF

SOUTHWESTERN NIGERIA.

International Journal of Research GRANTHAALAYAH, 9(3), 301-308. https://doi.org/10.29121/granthaa layah.v9.i3.2021.3567

Received Date: 17 February 2021

Accepted Date: 31 March 2021

Keywords:

Water

Sanitation

Households

Rural

\section{ABSTRACT}

The study examined the water sanitation facilities utilization among the rural households of south west Nigeria. The study specifically described the socio-economic characteristics of the rural household heads; identified various sources of water supply and their providers; examined the rural household heads' knowledge of water source contamination; examined respondents' awareness of adequate water treatment methods and the awareness of waterborne disease. The population of the study comprised of all the rural households in Ondo and Oyo States in Southwestern of Nigeria. The sampling procedure employed was multistage sampling technique to select 355 household heads comprising a total of 167 rural household considered out of 278 rural households from the selected cells in Oyo state while a total of 188 rural household heads selected out of 314 rural household heads from the selected cells in Ondo State for the study. The data for the study were analyzed with descriptive statistics such as frequency count, percentage, mean and standard deviation while inferential statistical tool such as logistic regression analysis model

The mean age of the respondents from Ondo State was 47 years while that of respondents from Oyo State was 45 years. Rain water collection was the major source of improved water supply from Ondo State $(87.4 \%)$ and Oyo State $(86.7 \%)$. In both Ondo and Oyo States, the knowledge of water source contamination is still on moderate level. Households in Ondo State (WMS $=2.98$ ) and Oyo State (WMS $=2.91$ ) were more aware of boiling of water as the major adequate water treatment methods. In both states, the awareness of adequate water treatment methods is still on moderate level. In both States, the awareness of water-borne diseases is still on moderate level, majority had favourable attitude towards utilization of water sanitation facilities while the level of utilization of water sanitation facilities is still on moderate level. The result of the Regression analysis model indicated that years of schooling $\left(\mathrm{t}=-3.758^{* * *} ; \mathrm{p}=0.000\right)$ and households' size $(\mathrm{t}=-$ $2.089^{* *}$; $\mathrm{p}=0.037$ ) were significantly related to utilization of water sanitation facilities.

It was therefore concluded that the utilization of water sanitation facilities was influenced by income level, knowledge of water source contamination, awareness of adequate water treatment methods, awareness of water-borne diseases, household size. The local council being the agency saddled with water provision, should be more empowered in terms of resources and facilities in order to be able to do their work of water provision and water sanitation information dissemination effectively. 
Assessment of Water Sanitation Facilities Utilization Among the Rural Households of Southwestern Nigeria

\section{INTRODUCTION}

Water covers more than two-thirds of the earth's surface, but mostly salty and undrinkable. The available freshwater resource is only $2.7 \%$ of the available water on earth but only $1 \%$ of the available freshwater (in lakes, rivers and groundwater) is accessible. Most of the available freshwater resources are inaccessible because they are in the hidden part of the hydrologic cycles (deep aquifers) and in glaciers (frozen in the polar ice), which means safe drinkable water on earth has very small proportion $(3 \%)$ in the freshwater resources. Freshwater can also be obtained from the seawater by desalinization process. In some countries, sufficient freshwater is not available (physical scarcity). In some countries, abundant freshwater is available, but it is expensive to use (economic scarcity).

In almost every region of the world, the demand for freshwater has continued to increase while accesses to the required quantity and quality of the resource have been on the decline (UNEP, 2000). The central role of water is evident in any systematic appraisal of life-sustaining requirements. Even at the most fundamental level of human survival and sustainable development, water not only has life sustaining qualities, but strongly influences economic activity (both production and consumption) and social roles. UNWATER (2006), estimates that 50\% of the world's population lacked access to safe sanitation while $20 \%$ lacked access to safe drinking water. Accessibility of people to safe drinking water and sanitation is crucial to sustainable development, and has great implications for socioeconomic growth and development. Human rights to water, public health and the environment, are also key index and crucial components of sustainable development (Moe and Rheingans 2006). Inaccessibility of people to safe drinking water and sanitation and the disparities can have a great impact on the health and well-being of vulnerable and the disadvantaged groups in the society, most especially, the children who are from poor households and the rural women (UNICEF, 2013). If the health, physical and emotional well-being of the members of the community is not in good shape, sustainable development will be elusive to the world over. Water and sanitation have great and significant impact on poverty-related phenomenon; therefore, sustainable development cannot be possible in an atmosphere of poverty which translates to poor living and unhealthy condition of the people (Sarmento, 2015).

Over the past decades, there have been various concerted efforts aimed at meeting basic water supply requirements of Nigeria. Despite these initiatives, it is estimated that a considerable percentage of the Nigerian population still lack minimum access to potable drinking water supply, improved sanitation and Hygiene (Water Sanitation Project (WSP), 2011). The government of Nigeria has failed to successfully deliver sustainable and equitable access to safe, adequate, improved and affordable water supply to most the of population over the years. Nigeria has the lowest life expectancy of around 47 years of age for adults in West Africa. This has been attributed to lot of health issues in the country, principally because of lack of access to safe drinking water, improved sanitation and hygiene (AfDB, OECD, UNDP, 2014). One out of every five children born in Nigeria may die before reaching the age of five due to the many health risks (World Population Review, 2014). Also, the country is one of five countries in the world which together accounts for half of under-five deaths, with Nigeria at 13\% (World Bank, 2013). Therefore, sustainable water supply would improve health and social wellbeing in the country. The problem of providing WATSAN facilities and services in Nigeria is probably challenged due to a nexus of factors including; natural, political, economic, and social among others. There is great evidence to suggest that, Nigeria is blessed with many natural water bodies such as rivers, streams, lakes among others that could be harnessed and used for both domestic and industrial purposes. However, the availability and accessibility of improved water for domestic consumption is yet to be achieved especially in the rural areas of Nigeria. This is because the provision of improved water sanitation facilities is generally seen as expensive enterprise for both government and donor agencies alike (Oclo, 2011 and Agyemin, 2011).

\section{METHODOLOGY}

The study was carried out in Oyo and Ondo States in Southwestern geopolitical Zone of Nigeria. The zone has six (6) states which are Oyo, Osun, Ondo, Ekiti, Ogun, and Lagos. The zone is located in the south west geographical zone of Nigeria. The zone lies in equatorial rainforest belt and the rainfall around this area varies from $1500 \mathrm{~mm}$ to $1800 \mathrm{~mm}$ per annum. They have distinct wet season from April to late October and dry season from November to March; the areas have a mean annual temperature of 26.2 degree Celsius, the humidity is high between July and December and low between December and February. The main occupation of the people is farming and farms are semi-commercial units, which largely rely on rainfall as main source of water supply. A multistage sampling 
technique was used in selecting a total of 167 rural household in Oyo state while a total of 188 rural households from the selected cells in Ondo state. This implies that a total of 355 rural household formed the sample size for this study. Primary data were collected from rural household's heads in South-western Nigeria. The data were collected with the use of well-structured interview schedule. The data for the study were analyzed with descriptive statistics such as frequency count, percentage, mean and standard deviation while inferential statistical tools such as logistic regression analysis model was used to test the hypothesis of the study.

\section{RESULTS AND DISCUSSION}

\subsection{SOCIO-ECONOMIC CHARACTERISTICS OF RESPONDENTS}

The distribution of respondents by age revealed that $8.7 \%$ were less than or equal to $8.7 \%, 21.7 \%$ were between 31 and 40 years, 38\% were between 41 and 50\%, 20.6\% were between 51 and 60 years of age while $11 \%$ were above 60 years of age. Majority (69\%) were male while 31\% were female. 10\% were single, majority (82\%) were married, $2.8 \%$ were divorced, $2.3 \%$ separated while another $2.8 \%$ were widowed. $60.3 \%$ were Christians, $39.7 \%$ were Muslims. According to level of education, $21.7 \%$ did not have formal education, 36.6\% completed Primary School, 31.3\% had Secondary education, 2.5\% attended College of Education and Polytechnic while 5.4\% attended University. $4.2 \%$ had 1 and 2 household size, 16.9\% had 3 and 4, 54.4\% had between 5 and 6 while 24.5\% had above 6 household size. A little below half (48.5\%) were Farmers, 31.8\% were traders, 8.5\% were Civil servants, $10.1 \%$ were into Artisanship while 1.1\% belong into category of unspecified others.

Table 1: Socio-economic Characteristics of Respondents

\begin{tabular}{|c|c|c|}
\hline Socio-economic & Frequency & Percentage \\
\hline Age (years) & 31 & \\
$\leq 30$ & 77 & 21.7 \\
$31-40$ & 135 & 38.0 \\
$41-50$ & 73 & 20.6 \\
$51-60$ & 39 & 11.0 \\
Above 60 & & \\
Sex & 245 & 69.0 \\
Male & 110 & 31.0 \\
Female & & \\
Marital Status & 36 & 10.0 \\
Single & 291 & 82.0 \\
Married & 10 & 2.8 \\
Divorced & 8 & 2.3 \\
Separated & 10 & 2.8 \\
Widowed & & \\
Religion & 214 & 60.3 \\
Christianity & 141 & 39.7 \\
Islam & 0 & 0.00 \\
Traditional & & \\
School last attended & 77 & 21.7 \\
None & 130 & 36.6 \\
Primary School & 111 & 31.3 \\
Secondary School & 9 & 2.5 \\
College of Education & 9 & 2.5 \\
Polytechnic & 19 & 5.4 \\
University & & \\
Household size & 15 & 4.2 \\
1-2 & 60 & 16.9 \\
3-4 & & \\
\hline
\end{tabular}


Assessment of Water Sanitation Facilities Utilization Among the Rural Households of Southwestern Nigeria

Source: Field Survey, 2020

\begin{tabular}{|c|c|c|}
$5-6$ & 193 & 54.4 \\
Above 6 & 87 & 24.5 \\
Primary Occupation & & \\
Farming & 172 & 48.5 \\
Trading & 113 & 31.8 \\
Civil service & 30 & 8.5 \\
Artisanship & 36 & 10.1 \\
Others & 4 & 1.1 \\
\hline
\end{tabular}

\subsection{KNOWLEDGE OF WATER SOURCE CONTAMINATION}

Table 2 shows the distribution of the respondents by their Knowledge of water contamination identified in the rank order include: bathing/washing clothes at water source (WMS=2.75), Indiscriminate use of fetcher (WMS=2.71), Do not have separate bucket or rope at the well/using dirty bucket (WMS=2.66), Poor storage practices (WMS =2.56). The animals can go into the water source. No fence/broken fence around the pond and No cover/lid to protect the well (WMS=2.53), Trash fallen into the water source (WMS=2.30), Dispose trash near the water source $(W M S=2.22)$, Urinate/Defecate at the water source (WMS $=2.19)$, Not properly plugging in the holes of the water pipe (WMS=2.04), Water that does not flow/stagnant water body/pond (WMS=1.99), Collection of acidic rain (WMS=1.95), Then well has no walling (WMS=1.90) and Washing raw meat and raw fish near the water source (WMS=1.87) and Latrine close to the water source (WMS=1.69)

Table 2: Distribution of Respondents by Knowledge of Water Source Contamination

\begin{tabular}{|c|c|c|c|c|c|c|}
\hline Water Source Contamination & Highly & Moderately & Lowly & $\begin{array}{c}\text { Not at } \\
\text { all }\end{array}$ & WMS & Rank \\
\hline Physical & & & & & & \\
\hline Bathing/washing clothes at water source & $279(78.6)$ & $64(18.0)$ & $12(3.4)$ & $0(0.0)$ & 2.75 & $1^{\text {st }}$ \\
\hline Urinate/Defecate at the water source & $176(49.6)$ & $70(19.7)$ & $108(30.4)$ & $1(0.3)$ & 2.19 & $9^{\text {th }}$ \\
\hline Latrine close to the water source & $121(34.1)$ & $46(13.0)$ & $145(40.8)$ & $43(12.1)$ & 1.69 & $15^{\text {th }}$ \\
\hline $\begin{array}{c}\text { Water that does not flow/stagnant water } \\
\text { body/pond }\end{array}$ & $147(41.4)$ & $62(17.5)$ & $141(39.7)$ & $5(1.4)$ & 1.99 & $11^{\text {th }}$ \\
\hline Dispose trash near the water source & $191(53.8)$ & $53(14.9)$ & $110(31.0)$ & $1(0.3)$ & 2.22 & $8^{\text {th }}$ \\
\hline Trash fallen into the water source & $211(59.4)$ & $45(12.7)$ & $94(26.5)$ & $5(1.4)$ & 2.30 & $7^{\text {th }}$ \\
\hline $\begin{array}{c}\text { Washing raw meat and raw fish near the water } \\
\text { source }\end{array}$ & $129(36.3)$ & $58(16.3)$ & $160(45.1)$ & $8(2.3)$ & 1.87 & $14^{\text {th }}$ \\
\hline $\begin{array}{c}\text { Not properly plugging in the holes of the water } \\
\text { pipe }\end{array}$ & $167(47.0)$ & $67(18.9)$ & $88(24.8)$ & $33(9.3)$ & 2.04 & $10^{\text {th }}$ \\
\hline $\begin{array}{c}\text { Do not have separate bucket or rope at the } \\
\text { well/using dirty bucket }\end{array}$ & $267(75.2)$ & $60(16.9)$ & $24(6.8)$ & $4(1.1)$ & 2.66 & $3^{\text {rd }}$ \\
\hline Then well has no walling & $136(38.3)$ & $60(16.9)$ & $147(41.4)$ & $12(3.4)$ & 1.90 & $13^{\text {th }}$ \\
\hline $\begin{array}{c}\text { The animals can go into the water source. No } \\
\text { fence/broken fence around the pond }\end{array}$ & $251(70.7)$ & $57(16.1)$ & $31(8.7)$ & $16(4.5)$ & 2.53 & $5^{\text {th }}$ \\
\hline No cover/lid to protect the well & $227(63.9)$ & $40(11.3)$ & $75(21.1)$ & $13(3.7)$ & 2.53 & $5^{\text {th }}$ \\
\hline Chemical & & & & & \\
\hline Collection of acidic rain & $197(55.5)$ & $30(8.5)$ & $43(12.1)$ & $85(23.9)$ & 1.95 & $12^{\text {th }}$ \\
\hline Microbiological & & & & \\
\hline Poor storage practices & $238(67.0)$ & $85(23.9)$ & $24(6.8)$ & $8(2.8)$ & 2.56 & $4^{\text {th }}$ \\
\hline
\end{tabular}

WMS = Weighted Mean Score

Source: Field Survey, 2020 


\subsection{AWARENESS OF ADEQUATE WATER TREATMENT METHODS}

Base on the result in Table 3. the adequate water treatment methods in the rank order of awareness as identified from the results are Boiling of water (WMS=2.94), Let it stand and settle and Use of Alum (WMS=2.92), Appropriate hand washing behaviours (WMS $=2.78$ ), Strain it through a cloth (WMS=2.77), Defecating in toilets/latrines (WMS=2.76), Add bleach/chlorine (WMS=2.70), Burning of garbage to control flies (WMS=2.69) and Solar disinfection (WMS $=0.59$ ).

The result of the finding therefore revealed that boiling of water was the most common and the adequate water treatment methods known among rural households in the selected States. Boiling of water before use may be associated with fact that the method is simple, easy to implement and effective outcome without the usage of sophisticated equipment. Moreover, adoption of any of the available water treatment methods could go a long way in preventing many waters borne diseases and death of rural households. In conformity with the present research finding, Cairncross and Valdmanis (2006) established that the spread of water- borne diseases can be contained by improved sanitation and hygiene. In the same vein, some scholars (Curtis and Cairncross, 2003; Fewtrell et al., 2005; Clasen et al., 2007) claimed that information, such as hand washing, sanitation, water treatment and safe drinking water storage have each been proven to reduce diarrhea rates by 30-40\%. Similarly, WHO (2014) noted that millions of children have been saved from premature death and illness related to malnutrition and preventable water-borne diseases resulting in a reduction in incidences of diarrhea, better maternal health, care for new-born and that adults in general now live longer and have healthier lives.

Table 3: Distribution of respondents by awareness of Adequate Water Treatment Methods in pooled data

\begin{tabular}{|c|c|c|c|c|c|c|}
\hline Water treatment methods & $\begin{array}{c}\text { Very Much } \\
\text { Aware }\end{array}$ & $\begin{array}{c}\text { Moderately } \\
\text { Aware }\end{array}$ & $\begin{array}{c}\text { Slightly } \\
\text { Aware }\end{array}$ & $\begin{array}{c}\text { Not } \\
\text { Aware }\end{array}$ & WMS & Rank \\
\hline Boiling of water & $341(96.1)$ & $9(2.5)$ & $3(0.8)$ & $2(0.6)$ & 2.94 & $1^{\text {st }}$ \\
\hline $\begin{array}{c}\text { Add bleach/chlorine } \\
\begin{array}{c}\text { Use a water filter (ceramic, sand, } \\
\text { composite, etc.) }\end{array}\end{array}$ & $275(77.5)$ & $54(15.2)$ & $26(7.3)$ & $0(0.0)$ & 2.70 & $7^{\text {th }}$ \\
\hline Solar disinfection & $28(7.9)$ & $36(10.1)$ & $52(14.6)$ & $239(67.3)$ & 0.59 & $9^{\text {th }}$ \\
\hline Strain it through a cloth & $300(84.5)$ & $39(11.0)$ & $7(2.0)$ & $9(2.5)$ & 2.77 & $5^{\text {th }}$ \\
\hline Let it stand and settle & $328(92.4)$ & $26(7.3)$ & $1(0.3)$ & $0(0.0)$ & 2.92 & $2^{\text {nd }}$ \\
\hline $\begin{array}{c}\text { Appropriate hand washing } \\
\text { behaviours }\end{array}$ & $296(83.4)$ & $47(13.2)$ & $6(1.7)$ & $6(1.7)$ & 2.78 & $4^{\text {th }}$ \\
\hline Burning of garbage to control flies & $272(76.6)$ & $60(16.9)$ & $20(5.6)$ & $3(0.8)$ & 2.69 & $8^{\text {th }}$ \\
\hline Defecating in toilets/latrines & $292(82.3)$ & $47(13.2)$ & $10(2.8)$ & $6(1.7)$ & 2.76 & $6^{\text {th }}$ \\
\hline Use of Alum & $332(93.5)$ & $18(5.1)$ & $5(1.4)$ & $0(0.0)$ & 2.92 & $2^{\text {nd }}$ \\
\hline
\end{tabular}

$\operatorname{Mean}(\overline{\times})=24.50 ;$ S.D $=2.369$

WMS $=$ Weighted Mean Score

Source: Field Survey, 2020

\subsection{AWARENESS OF WATER-BORNE DISEASE}

Table 4 showed the distribution of respondents by awareness of water-borne diseases. Based on the result in the Table 4.10, the awareness of water-borne diseases in the rank order of awareness as identified from Oyo State include diarrhea (WMS $=2.01$ ), cholera (WMS = 1.99), guinea worm (WMS = 1.95), malaria (WMS = 1.90), typhoid (WMS = 1.79), scabies (WMS $=1.74)$, schistosomiasis $(W M S=0.46)$ and onchoceriasis $(W M S=0.35)$. The finding therefore indicates that rural households in the selected States were confronted with diverse water-borne diseases of which diarrhea was identified as the most prominent of them due to consumption of unhygienically sanctified water (poor water and sanitation). The finding therefore indicates that rural households in the selected States were confronted with diverse water-borne diseases of which diarrhea was identified as the most prominent of them due to consumption of unhygienically sanctified water (poor water and sanitation). In line with the finding of this study, UN (2003) affirmed that many developing countries, as much as $80 \%$ of illnesses are linked to poor water and sanitation conditions. Similarly, it is estimated by some agencies (UNEP/UN-HABITAT, 2009) that half of the world's 
hospital beds are filled with people suffering from a water-related disease. Conversely, WHO/UNICEF (2009) opined that nearly 1 out of every 5 deaths under the age of 5 worldwide is due to a water-related disease. Child mortality according to UNDP (2010) is considered higher amongst households with poor access to clean water and sanitation facilities.

Table 4: Distribution of respondents by awareness of Water-Borne Disease

\begin{tabular}{|c|c|c|c|c|c|c|}
\hline Waterborne Diseases & Very Much Aware & Moderately Aware & Slightly Aware & None & WMS & Rank \\
\hline Diarrhea & $6(1.7)$ & $348(98.0)$ & $1(0.3)$ & $0(0.0)$ & 2.01 & $1^{\text {st }}$ \\
\hline Typhoid & $1(0.3)$ & $283(79.7)$ & $68(19.2)$ & $3(0.8)$ & 1.79 & $5^{\text {th }}$ \\
\hline Scabies & $4(1.1)$ & $274(77.2)$ & $58(16.3)$ & $19(5.4)$ & 1.74 & $6^{\text {th }}$ \\
\hline Schistosomiasis & $0(0.0)$ & $44(12.4)$ & $77(21.7)$ & $234(65.9)$ & 0.46 & $7^{\text {th }}$ \\
\hline Guinea worn & $14(3.9)$ & $314(88.5)$ & $23(6.5)$ & $4(1.1)$ & 1.95 & $3^{\text {rd }}$ \\
\hline Onchoceriasis & $0(0.0)$ & $28(7.9)$ & $68(19.2)$ & $259(73.0)$ & 0.35 & $8^{\text {th }}$ \\
\hline Cholera & $11(3.1)$ & $33(93.2)$ & $13(3.7)$ & $0(0.0)$ & 1.99 & $2^{\text {nd }}$ \\
\hline Malaria & $6(1.7)$ & $308(86.8)$ & $39(11.0)$ & $2(0.6)$ & 1.90 & $4^{\text {th }}$ \\
\hline
\end{tabular}

WMS = Weighted Mean Score

Source: Field Survey, 2020

\subsection{LEVEL OF UTILIZATION OF WATER SANITATION FACILITIES}

The utilization of Clean and covered containers was ranked highest among utilized water sanitation facilities with a weighted mean score (WMS) of 2.92. Others in their rank order include use of Soapy water (WMS $=2.91)$, hand washing (WMS $=2.90)$, boiling (WMS $=2.86$ ), protected well (WMS $=2.78$ ), improved sewage containers (WMS = 2.73), hand pump (WMS = 2.60), point of use water treatment with additives (WMS = 2.56), borehole (WMS = 2.45), public stand pipes (WMS $=1.03$ ), solar disinfectant (WMS $=0.90)$, filter technology (WMS $=0.85$ ), hand sanitizers $(\mathrm{WMS}=0.75$ ) and Ultraviolet filtration device (WMS $=0.62$ ). The use of clean and covered container was the major method used by the respondents in the southwestern Nigeria. The use of clean and covered containers could help reduce adulteration of water source thereby reducing incidence of water-borne diseases. This finding indicates that utilization of water sanitation facilities will go a long way in reducing incidence of water-borne diseases. In line with the present finding, Centers for Disease Control (2014) claimed that majority of household water treatment and storage, including: filter technologies, point-of-use water treatment with chemicals additives (for example sodium hypochlorite-based water treatment systems), ultraviolet filtration devices, solar disinfection, boiling, and modified or improved water storage containers.

Table 5: Distribution of respondents by utilization of Water Sanitation Facilities

\begin{tabular}{|c|c|c|c|c|c|c|}
\hline Water Sanitation Facilities & Always & Sometimes & Rarely & Never & WMS & Rank \\
\hline \multirow{3}{*}{$\begin{array}{c}\text { Household Water Treatment Storage } \\
\text { Filter technology } \\
\text { Point of use water treatment with additives }\end{array}$} & & & & & & \\
\hline & $49(13.8)$ & $55(15.5)$ & $45(12.7)$ & $206(58.0)$ & 0.85 & $12^{\text {th }}$ \\
\hline & $246(69.3)$ & $77(21.7)$ & $20(5.6)$ & $12(3.4)$ & 2.57 & $8^{\text {th }}$ \\
\hline \multirow{5}{*}{$\begin{array}{l}\text { Ultraviolet filtration device } \\
\text { Solar disinfectant } \\
\text { Boiling } \\
\text { Clean and covered containers } \\
\text { Improved sewage containers }\end{array}$} & $29(8.2)$ & $47(13.2)$ & $38(10.7)$ & $241(67.9)$ & 0.62 & 14th \\
\hline & $76(21.4)$ & $33(9.3)$ & $25(7.0)$ & $221(62.3)$ & 0.90 & $11^{\text {th }}$ \\
\hline & $320(90.1)$ & $24(6.8)$ & $8(2.3)$ & $3(0.8)$ & 2.86 & $4^{\text {th }}$ \\
\hline & $327(92.1)$ & $28(7.9)$ & $0(0.0)$ & $0(0.0)$ & 2.92 & $1^{\text {st }}$ \\
\hline & $276(77.7)$ & $61(17.2)$ & $18(5.1)$ & $0(0.0)$ & 2.73 & $6^{\text {th }}$ \\
\hline \multicolumn{7}{|l|}{ Hand washing hardware } \\
\hline \multirow{3}{*}{$\begin{array}{l}\text { Hand washing } \\
\text { Soapy water } \\
\text { Hand sanitizers }\end{array}$} & $327(92.1)$ & $24(6.8)$ & $1(0.3)$ & $3(0.8)$ & 2.90 & $3^{\text {rd }}$ \\
\hline & $330(93.0)$ & $21(5.9)$ & $1(0.3)$ & $3(0.8)$ & 2.91 & $2^{\text {nd }}$ \\
\hline & $18(5.1)$ & $41(11.5)$ & 131(36.9) & $165(46.5)$ & 0.75 & $13^{\text {th }}$ \\
\hline \multicolumn{7}{|l|}{ Water supply technologies } \\
\hline \multirow{2}{*}{$\begin{array}{c}\text { Hand pump } \\
\text { Borehole }\end{array}$} & $277(78.0)$ & $25(7.0)$ & $43(12.1)$ & $10(2.8)$ & 2.60 & $7^{\text {th }}$ \\
\hline & $243(68.5)$ & $42(11.8)$ & $56(16.8)$ & $14(3.9)$ & 2.45 & $9^{\text {th }}$ \\
\hline
\end{tabular}


Adewole W.A., Ayoade A.R., Olaniyi O.A, and Oladapo E.O.

\begin{tabular}{|c|c|c|c|c|c|c|}
\hline \multirow{2}{*}{$\begin{array}{c}\text { Protected well } \\
\text { Public stand pipes }\end{array}$} & $290(81.7)$ & $55(15.5)$ & $7(2.0)$ & $3(0.8)$ & 2.78 & $5^{\text {th }}$ \\
\cline { 2 - 7 } & $39(11.0)$ & $42(11.8)$ & $163(45.9)$ & $111(31.3)$ & 1.03 & $10^{\text {th }}$ \\
\hline
\end{tabular}

WMS = Weighted Mean Score

Source: Field Survey, 2020

\section{Hypotheses Testing}

\subsection{INFLUENCE OF SELECTED SOCIO-ECONOMIC CHARACTERISTICS OF RESPONDENTS ON THE UTILIZATION OF WATER SANITATION FACILITIES}

\section{$\mathrm{HO}_{1}$ : There is no significant relationship between selected socio-economic characteristics and level of utilization of water sanitation facilities.}

The result of the Regression analysis model in the Table 6 indicated that years of schooling $\left(\mathrm{t}=-3.758^{* * *}\right.$; $\mathrm{p}=0.000)$ and households' size $\left(\mathrm{t}=-2.089^{* *} ; \mathrm{p}=0.037\right)$ were significantly related to utilization of water sanitation facilities. Household size indicated inverse and significant relationship with utilization of water sanitation facilities at $5 \%$ significant level, implying that the probability of utilization of water sanitation facilities decreases with an increase in household size. The odds ratio in favour of utilization of water sanitation facilities decreases by the factor -0.249 as the household size is increased by one member. An increase means few households' members contribute to households' water provision through utilization of water sanitation facilities which could be due to financial incapability. The likely explanation is that in an area where households depend on large water supply, increasing household size (active members) results in increased water consumption which might make them utilize available water supply source without must consideration of safety of water leading to not utilizing water sanitation facilities.

The coefficient of years of schooling was also inverse indicating that there is inverse relationship between years of schooling and utilization of water sanitation facilities. Years of schooling is significant at $1 \%$. The odds ratio in favour of utilization of water sanitation facilities decreases by the factor -0.124 for a unit increase in the years of schooling. This result could be because education offers more exposure and that could limit their consumption of water or utilization of water facilities like borehole instead of the utilization of multiple water sanitation facilities.

Table 6: Summary of regression analysis model showing relationship between socio- economic characteristics of respondents and households' food security level

\begin{tabular}{|c|c|c|c|c|c|}
\hline SEC & B-value & Standard error & T-value & P-value & Remarks \\
\hline Constant & 31.492 & 0930 & $33.879^{* * *}$ & 0.000 & \\
\hline Age & -0.007 & 0.016 & -0.443 & 0.658 & NS \\
\hline Years of schooling & -0.124 & 0.033 & $-3.758^{* * *}$ & 0.00 & $\mathrm{~S}$ \\
\hline Household size & -0.249 & 0.119 & $-2.089^{* *}$ & 0.037 & $\mathrm{~S}$ \\
\hline
\end{tabular}

Mean squares $=48.739 ; F=5.415 ; R=0.210 ; R$-Square $=0.044 ;$ Adjusted $R$-Square $=0.036 ;$ Std. error of the estimate $=3.000$ $S=$ Significant, $N S=$ Not Significant

${ }^{* * *}=$ Significant at $1 \%$ level, ${ }^{* *}=$ Significant at $5 \%$ level

Source: Data Analysis, 2020

\section{CONCLUSION AND RECOMMENDATION}

It was therefore concluded that the utilization of water sanitation facilities were influenced by income level, knowledge of water source contamination, awareness of adequate water treatment methods, awareness of waterborne diseases, household size. Since the local government council is saddled with the main responsibility of water provision according to the federal government of Nigeria and the main findings of this study, the local council should be more empowered in terms of resources and facilities in order to be able to do their work of water provision and water sanitation information dissemination effectively. 


\section{SOURCES OF FUNDING}

This research received no specific grant from any funding agency in the public, commercial, or not-for-profit sectors.

\section{CONFLICT OF INTEREST}

The author have declared that no competing interests exist.

\section{ACKNOWLEDGMENT}

None.

\section{REFERENCES}

[1] Moe, C. L., and Rheingans, R. D. (2006) Global challenges in water, sanitation and health. Journal of water and health, 4(S1), pp.41-57. Monitoring Programme on Water Supply and Sanitation. WHO/UNICEF

[2] Sarmento, D. R. (2015). An Analysis of Access to Improved Drinking Water and Sanitation and Distance to the Water Source in a Newly Independent Country, Timor-Leste: Assessing Geographical and Socioeconomic Disparities (Doctoral dissertation, ScholarWorks@ Georgia State University).

[3] UNEP, (2000). Global Environmental Outlook 2000, UNEP Earth Scan 1997, UK.

[4] UNICEF (2013). Joint Monitoring Programme (JMP) for Water Supply and Sanitation. 2013 update. ISBN 978 9241505390.

[5] UN-WATER, (2006). Water for wealth creation and health environment.

[6] WSP (2011) Economic Impacts of poor sanitation in Africa. [Online] Water and Sanitation Program

[7] World Bank (2013). Timor-Leste-Country partnership strategy for the period FY2013-2017. World Bank: Washington, DC. 